\title{
A STUDY ON THE REDUCTION OF THE MAIN SHAREHOLDING OF THE GROWTH ENTERPRISE MARKET
}

\author{
Ling Qiao \\ Shanghai University, P.R.China
}

\begin{abstract}
The reduction of major shareholders of listed companies has always been the focus of the market, the important shareholders "clearance" reduction of the case is more common. As of today, the GEM in April 2016 to now, there are 479 listed companies, which have a significant reduction in the behavior of shareholders. After the split share structure reform, the original cannot be listed in the circulation of restricted shares gradually into the secondary market, and lead the formation of the full circulation of China's stock market. However, the concerns of shareholders are from the previous net assets of the company to changing the price of the stock, then raising the stock price, reduction of major shareholders become the foothold of a major shareholder after the lifting of the ban. In this paper, factor analysis and multiple regression analysis are used to find out the main factors influencing the motivations of the major shareholders of the GEM. It is hoped that the above research will provide reference for the policy making of the supervisory authority and the investment decision of the minority shareholders. In addition, through theoretical analysis, we can find the best time to reduce shareholder holdings, to balance the liquidity of the capital market.
\end{abstract}

Keywords: GEM major shareholder holdings of motivation

\section{JEL code: C3}

\section{Introduction}

There is a growing concern on influencing factors of reducing behavior of major shareholders. However, the present study has not yet come to a unified conclusion. In foreign countries, the pros and cons of insider trading has always been one of the most controversial topics in academia. Manne (1966) first proposed that insider trading can be used as an effective reward mechanism to inspire insiders to innovate, insiders can bear the risk of the project by buying the stock before the information is disclosed, and sell the stock after the stock price rise as compensation for the insider's innovation; Givoly and Palmon (1985) based on data from the US securities market, they agreed that insiders had an advantage in information and were able to earn excess returns; Chen Xiaodong and Chen Xiaoyue(2003) believe that the change of the largest shareholder is conductive to the improvement of corporate governance, and is conductive to the expansion of the company's scale and the specialization of management; Berle and Means (1932) first proposed the theory of control structure, they believe that the company's shareholding concentration is worse, the operating performance is lower; on the 
contrary, the company's equity concentration is higher, the performance is higher. In the domestic research, Zeng Qingsheng (2008) believes that executives and major shareholders in the A-share market could; select the ability to obtain excess profits, and in the reduction, the stock fell; Ba Shusong, Zhu Yuanqian, Zheng Hong (2008) believe that the main purpose of shareholder holdings is to obtain revenue, which should be selected in the company is overvalued period of reduction. Wu Yuhui and Wu Shinong (2010) think, compared with the non-controlling shareholder, the controlling shareholder or the actual controller information control is more serious, the abnormal rate of return is also higher.

Based on the above domestic and foreign research, this paper mainly uses multiple linear regression model to study the effects of major shareholder reduction behavior, especially in the Growth Enterprise Market.

\section{Statement of problem}

To meet the needs of market development, China establish the GEM following the small and medium-sized board market, specifically to provide services for the growth of small and medium enterprises. Since October 30, 2009, the GEM board to attract the enthusiasm of the majority investors, and the emergence of "three high" phenomenon: high issue price, high priceearnings ratio and high raised funds, but not long before the GEM market will be restricted sales Shareholders holdings of cash, its holdings of strength not only has brought pressure to the secondary market, but also to the vast number of investors facing huge losses. Major shareholder reduction behavior often reflects the company's information. as a long-term concern about the company or the core figures of company's operating situation, major shareholder reduction is often a guide for investors, when the shot reduction of the company's stock, the current share price is not recognized. Therefore, the reduction in behavior is considered that the company's share price is overvalued. Based on the current pressure of lifting and holdings, this paper takes the reduction of the major shareholders of the GEM from April 2016 to April 2017 as the research object, explores and validates the factors that affect the reduction behavior. Finally, through the study of information disclosure on the GEM market and the reduction of the status quo, we choice two angles of information manipulation and earnings management on the GEM market to research the timing of the reduction of major shareholders theoretically.

\section{3. the theoretical analysis and research assumptions}

\section{1 reduction of motivation related theory}

(1) Tobin Q theory: economic society includes two kinds of assets, namely, physical assets and financial assets. The growth of social and economic production cannot be separated from the continuous investment of physical assets, by issuing financial assets to finance for the physical assets, and ultimately distributing the financial assets under the rights and obligations after creating income in the physical assets. In 1969, the "Q" ratio proposed by James Tobin to expound the general equilibrium and transmission mechanism between the physical assets and 
financial assets systematically. Tobin Q refers to the ratio of market value to replacement cost. When the value of the stock is overvalued, it will sell the financial assets to the real estate. The shareholders tend to earn the market premium to sell the stock.

(2) Analysis on the influence of restricted stock release on the stock market:

Venture capitalist holdings is one of the characteristics of the GEM, venture capital transfer to achieve the withdrawal, the low cost of investment decided that once the restricted shares lifted, venture capital firms are likely to sell the stock, in addition, under the temptation of high value, the major shareholders owning information advantage will choose to avoid the long-term risk of operating companies to realize wealth "landing for security." From an economic point of view, the stock as a financial asset, its price is determined by the supply and demand. The lifting of the restricted shares increased the number of tradable shares, when the stock supply increased, the supply curve shifted to the right, the stock price fall. In addition, the sale of restricted shares of large shareholders will bring the company's negative information, the stock price will further fell through the "cluster phenomenon".

(3) The company's financial performance:

The company's financial performance includes growth capacity, solvency, operational capacity and profitability. The company's financial performance is good that its comprehensive is strength, the shareholders can optimistic to the company's future and reduce the behavior of reduction. That is, the factors that affect the company's performance is bound to change the holding behavior of major shareholders. When the company's solvency is impaired, the high proportion of debt is likely to bring financial risk. To avoid the financial risk, shareholders are more willing to reduce; when the company has a high growth, shareholder holdings will get larger and faster interest, then it will not be easily reduced. In short, to maximize their own interests, shareholders will be based on financial indicators to decide whether the reduction.

(4) Ownership structure theory:

Ownership structure is the basis of corporate governance, including the composition of shares and equity concentration. to the GEM, the lifting of the ban will result in changes in ownership structure, after the reduction, the major shareholders who own absolute control of the company will not only lose their control of the company, but also loss of control premium income, so its reduction ratio will be lower than those who have no control of the venture capital holders.

\section{2 reduction of research assumptions}

Assumption 1: the number of reduction of major shareholders is proportional to the corporate Tobin Q value;

Hypothesis 2: The number of reduction of major shareholders is positively related to the number of restricted shares.

Hypothesis 3: The reduction in the number of major shareholders is inversely proportional to the company's financial performance;

Hypothesis 4: The reduction in the number of major shareholders is inversely proportional to the concentration of ownership. 


\section{4. the major motivation of shareholder holdings}

\section{1 model design and variable selection}

the explanatory variable: the number of major shareholders holdings $\mathrm{Y}$ explain the variables:

1) the company valuation level - Tobin $Q$ value, $q=$ market value / total assets, if the $Q$ value is greater than 1, that means, the company's market value is greater than the replacement cost, indicating that the stock is overvalued and the investment risk is larger, the shareholders are easy to sell the stock. If the Q value is less than 1, the market value of the company is less than the replacement cost. At the same time, the investment risk is small, the assets are safe and the shareholders will not reduce the holdings.

2) the number of restricted shares lifted.

3) Company performance - the company's net return on assets ROE, equal to the company's net profit to the company's net assets, measured after-tax profits of per share. Its essence is the ratio of input and output, reflecting the company's efficiency on the usage of its own capital. the indicator become higher, the benefits of the investment will be larger and the shareholder's motivation to reduce will be smaller.

4) Company ownership structure - the top ten shareholders shareholding ratio.

\section{2 sample selection and data sources}

This article selected the GEM secondary market major shareholder reduction data between April 2016 and April 2017 as the study sample, excluding the stock by the ST companies, which are not the same rate of decline and often exist speculation. In addition, this article also removed the companies which hold stock less than a year and take reorganization, backdoor and other major events after holding reduction.

Finally, we got 64 valid samples, the sample companies occurring holdings reduction and financial indicators, the number of lifting are from the wind information database.

\section{3 variable descriptive statistics}

The descriptive statistics of the explanatory and explanatory variables are given in the table. The number of reductions and the number of lifted are wide, and the difference between the maximum and the minimum is large and the corresponding standard deviation is large. The minimum Tobin $\mathrm{q}$ is greater than 1 , the stock overvaluation is more obvious. 
Table 1 Variable description statistics

\begin{tabular}{|l|l|l|l|l|l|l|}
\hline & obs & mean & std.dev & $\max$ & min & median \\
\hline Number of reductions $\mathrm{y}$ & 64.00 & 1692.52 & 2793.36 & 16865.74 & 0.03 & 650.71 \\
\hline Tobin q $\left(\mathrm{x}_{1}\right)$ & 64.00 & 3.02 & 1.92 & 10.93 & 1.16 & 2.54 \\
\hline ROE $\left(\mathrm{x}_{2}\right)$ & 64.00 & 1.44 & 1.69 & 10.08 & $(1.21)$ & 1.11 \\
\hline The number of lifted $\left(\mathrm{x}_{3}\right)$ & 64.00 & 4634.35 & 7110.46 & 36421.39 & 28.12 & 2126.02 \\
\hline $\begin{array}{l}\text { Top10shareholdersshareholding } \\
\text { ratio }\left(\mathrm{x}_{4}\right)\end{array}$ & 64.00 & 49.85 & 11.28 & 79.70 & 16.74 & 49.16 \\
\hline
\end{tabular}

\section{4 establish multiple regression analysis model}

The regression results are as following:

$$
\mathrm{y}=\beta_{0}+\beta_{1} x_{1}+\beta_{2} x_{2}+\beta_{3} x_{3}+\beta_{4} x_{4}
$$

Table 2 The estimation results

\begin{tabular}{lllll}
\hline \hline Variable & Coefficient & Std. Error & t-Statistic & Prob. \\
\hline \hline C & -1655.308 & 1286.396 & -1.286780 & 0.2034 \\
X1 & 43.11120 & 162.7301 & 0.264924 & 0.7920 \\
X2 & 312.2621 & 183.5698 & 1.701054 & 0.0944 \\
X3 & 0.256182 & 0.037872 & 6.764502 & 0.0000 \\
X4 & 32.21370 & 24.16482 & 1.333082 & 0.1878 \\
\hline \hline R-squared & 0.484316 & Mean dependent var & 1719.814 \\
Adjusted R-squared & 0.448128 & S.D. dependent var & 2807.679 \\
S.E. of regression & 2085.771 & Akaike info criterion & 18.20087 \\
Sum squared resid & $2.48 \mathrm{E}+08$ & Schwarz criterion & 18.37241 \\
Log likelihood & -559.2270 & Hannan-Quinn criter. & 18.26822 \\
F-statistic & 13.38323 & Durbin-Watson stat & 2.062939 \\
Prob(F-statistic) & 0.000000 & & \\
\hline \hline
\end{tabular}

Therefore, the function of the number of major shareholders and the company's performance is as following:

$$
\begin{gathered}
\mathrm{y}=-1655.308+43.111 x_{1}+312.262 x_{2}+0.256 x_{3}+32.214 x_{4} \\
R^{2}=0.4843 \quad \bar{R}^{2}=0.4481 \quad F=13.3832
\end{gathered}
$$

The calculation results of the model show that the marginal value of Tobin $q$ is 43.111 , the marginal value of return on net assets is 0.7764 , the marginal value of the number of restricted shares is 0.256 , the impact of the holding proportion of the top ten shareholders will increase 
the number of shareholders holdings, which increase 32.214 million shares annually. The symbols and values of the regression coefficients are more reasonable. As can be seen from Figure $3-1$, the statistical value of the explanatory variable $\mathrm{x} 1$ is 0.265 , and the statistic value relative to the other variables is too small to pass the test. Therefore, we need to do the appropriate adjustments to the above four linear regression models, in accordance with the statistical test procedures, the general should first remove the variables with smallest $t$ value (time variables) and re-establish the model.

After removing $\mathrm{x} 1$, we create a new function expression:

$$
\mathrm{y}=\gamma_{0}+\gamma_{1} x_{2}+\gamma_{2} x_{3}+\gamma_{3} x_{4}
$$

The test results are as follows:

Table 3 The estimation results

\begin{tabular}{lllll}
\hline \hline Variable & Coefficient & Std. Error & t-Statistic & Prob. \\
\hline \hline C & -1551.832 & 1215.801 & -1.276387 & 0.2069 \\
X2 & 336.6182 & 157.6101 & 2.135766 & 0.0369 \\
X3 & 0.254439 & 0.036995 & 6.877569 & 0.0000 \\
X4 & 32.23900 & 23.97015 & 1.344964 & 0.1839 \\
\hline \hline R-squared & 0.483682 & Mean dependent var & 1719.814 \\
Adjusted R-squared & 0.456975 & S.D. dependent var & 2807.679 \\
S.E. of regression & 2068.984 & Akaike info criterion & 18.16984 \\
Sum squared resid & $2.48 \mathrm{E}+08$ & Schwarz criterion & 18.30708 \\
Log likelihood & -559.2652 & Hannan-Quinn criter. & 18.22373 \\
F-statistic & 18.11126 & Durbin-Watson stat & 2.056331 \\
Prob(F-statistic) & 0.000000 & & \\
\hline \hline
\end{tabular}

Obviously, the statistical value and F statistics have improved, to improve the accuracy of the function, we make a white test to the function, the results are as follows: 
Table 4 Heteroskedasticity Test: White

\begin{tabular}{cccc}
\hline \hline F-statistic & 9.320749 & Prob. F (9,53) & 0.0000 \\
Obs*R-squared & 38.60757 & Prob. Chi-Square (9) & 0.0000 \\
Scaled explained SS & 66.64952 & Prob. Chi-Square (9) & 0.0000 \\
\hline \hline
\end{tabular}

Test Equation:

\begin{tabular}{ccccc}
\hline \hline Variable & Coefficient & Std. Error & t-Statistic & Prob. \\
\hline \hline C & -954080.0 & 9079777. & -0.105077 & 0.9167 \\
X2 & -282414.2 & 3211703. & -0.087933 & 0.9303 \\
X2^2 & -35894.16 & 119316.0 & -0.300833 & 0.7647 \\
X2*X3 & -71.34002 & 121.6107 & -0.586626 & 0.5599 \\
X2*X4 & 23758.49 & 54549.55 & 0.435540 & 0.6649 \\
X3 & -779.8027 & 651.5566 & -1.196830 & 0.2367 \\
X3^2 & 0.017558 & 0.010774 & 1.629567 & 0.1091 \\
X3*X4 & 22.53417 & 15.36517 & 1.466575 & 0.1484 \\
X4 & 56206.26 & 372584.4 & 0.150855 & 0.8807 \\
X4^2 & -540.1982 & 3845.303 & -0.140483 & 0.8888 \\
\hline R-squared & 0.612819 & Mean dependent var & 3987754. \\
Adjusted R-squared & 0.547071 & S.D. dependent var & 7975697. \\
S.E. of regression & 5367645. & Akaike info criterion & 33.97429 \\
Sum squared resid & $1.53 E+15$ & Schwarz criterion & 34.31447 \\
Log likelihood & -1060.190 & Hannan-Quinn criter. & 34.10809 \\
F-statistic & 9.320749 & Durbin-Watson stat & 2.204122 \\
Prob(F-statistic) & 0.000000 & & & \\
\hline \hline
\end{tabular}

Where $\mathrm{F}$ is the $\mathrm{F}$ statistic value of the auxiliary regression model. Taking a significant level $\alpha=0.05$, due to $\chi_{0.05}^{2}(2)=5.99<n R^{2}=38.607$, there exist the heteroskedasticity. And then we also take the partial correlation coefficient test, results are as follows, indicating that there is no autocorrelation. 
Table 5 The result of the partial correlation coefficient test

\begin{tabular}{|c|c|c|c|c|c|c|}
\hline Autocorrelation & Partial Correlation & & $\mathrm{AC}$ & PAC & Q-Stat & Prob \\
\hline. $\mid$. &. $\mid$ & 1 & -0.039 & -0.039 & 0.0992 & 0.753 \\
\hline.$|\cdot \quad|$ &.$|\cdot \quad|$ & 2 & 0.017 & 0.015 & 0.1179 & 0.943 \\
\hline$.\left.\right|^{*} . \quad \mid$ &.$\left.\right|^{*}$ & 3 & 0.134 & 0.135 & 1.3406 & 0.720 \\
\hline. $\mid$ &. $\mid$ & 4 & 0.036 & 0.047 & 1.4300 & 0.839 \\
\hline$*^{*} . \quad \mid$ & $.^{*} . \quad \mid$ & 5 & -0.144 & -0.149 & 2.8927 & 0.717 \\
\hline.$\left.\right|^{*}$ & $\left.\right|^{*}$ & 6 & 0.123 & 0.095 & 3.9769 & 0.680 \\
\hline.$|. \quad|$ &. $\mid$ & 7 & 0.010 & 0.016 & 3.9840 & 0.782 \\
\hline.$|. \quad|$ &.$|. \quad|$ & 8 & -0.050 & -0.020 & 4.1672 & 0.842 \\
\hline$. * 1 . \quad \mid$ & $.^{*} . \quad \mid$ & 9 & -0.162 & -0.192 & 6.1476 & 0.725 \\
\hline.$^{*}|. \quad|$ & $* * \mid$ & 10 & -0.187 & -0.248 & 8.8611 & 0.545 \\
\hline
\end{tabular}

It can be seen from the figure that the linear correlation coefficient of the linear model does not exceed the dotted line, so there is no first order autocorrelation. Therefore, the final major shareholder reduction function is:

$$
\begin{gathered}
\mathrm{y}=-1551.832+336.6182 x_{2}+0.2544 x_{3}+32.2390 x_{4} \\
\mathrm{t}=(-1.2764) \quad(2.1357) \quad(6.8775) \quad(1.3449)
\end{gathered}
$$

\section{5. the opportunity of the major shareholders holdings}

\section{1 information manipulation and reduction}

Large shareholders are special groups with information advantages, they tend to use the company's valuation and the advantages of information in operating results to seek their own interests, they can directly participate in the company's business decision-making activities, and firstly detect the company's performance changes. In the securities market, the information asymmetry phenomenon is more general, the major shareholders have two parts of advantages in insider information and value judgments, so there will be a problem in strategy of trading timing options. To win excess returns, the reduction of major shareholders will be selected within one year after the lifting of the ban, and generally choose reduction before bad news be published. 


\subsection{Earnings management}

Foreign holdings have found that there is a clear positive earnings management before the reduction. For the GEM, there are less requirements for the company to go public, and almost of them are the innovative companies, with a clear "three high" features, the marketization of wealth make the major shareholders have strong motivation to manage earnings management, so some shareholders are not to control the capital right of the market, but to get a high return on investment after withdrawing from the market. In this way, to tie in with the reduction, the major shareholders will generally be in the positive earnings management before the reduction.

\section{Conclusions and policy recommendations}

Theoretically, the size of reduction depends on the investor's expectations for the market and it is highly relevant to the risk appetite. Assuming the market is neutral, the stock is climbing steadily and the valuation is rising, the willingness of the rational investors to increase will rise. When the valuation premium is too high, the scale is enlarged, the stock price will be suppressed, and the stock price will fall. Therefore, the major shareholders holdings are both the reason and the result.

First, for the reduction motivation of large shareholders. Major shareholders' holdings are largely determined by the outlook for listed companies, who tend to invest in the company's long-term interests and reduce their holdings on a stock-based basis, their behaviors in holdings are determined with more prudent actions and more reasonable. Large shareholders are more inclined to higher level of reduction in the case of a lower valuation of enterprises, when corporate stocks are overvalued in the situation, from the long-term consideration, the future is likely to fall in stock prices, so the first choice to reduction is on the high price of stock. In terms of the ownership structure of the company, the equity concentration of the listed companies on the GEM is higher, the proportion of shareholders holdings is lower.

Second, for the major shareholder reduction time. after the restricted shares lifted, most of the reductions are lifted after six months to one year, on the one hand, this is due to China's GEM market, which has the "three high" issue that lead to the inevitable result, but also strongly reflects that shareholders are not confident in the company's growth and operating conditions. there is a certain degree of information manipulation of major shareholders holdings in the restricted shares after the lifting of the ban, and they always passively use their advantages of value judgment to determine the proper time to reduce before publishing bad new ${ }^{[5]}$. In addition, the major shareholders have a more obvious earnings management in the restricted shares before the lifting of the ban. The companies listed on GEM are to achieve growth requirements, they generally make positive earnings management, in the year before the reduction, their earnings management increased significantly, after that, the earnings management level decreased significantly.

Third, improve the ownership structure of the GEM and corporate governance. China's actual control of the GEM companies are mostly the first generation of entrepreneurship of private entrepreneurs, so the company's shareholding structure and corporate governance are still not 
perfect. The company's equity structure can be listed as one of the conditions by the relevant departments, so that the GEM shares are relatively dispersed to play more good checks and balances, and to ease the holdings of shareholders holdings at a certain extent. On the other hand, the independent director system of the division in China's GEM is also to be improved, and the effective supervision of the independent directors can make more independent directors functions and reduce the interests of large shareholders on the invasion of small shareholders

\section{References}

Berle, A. \& G. Means. (1932) The Modern Corporation and Private Property. New York: Mae Millan Press.

Givoly, D.\& D. Palmon. (1985) "Insider Trading and the Exploitation of Inside Information: Some Empirical Evidence”. Journal of Business, vol. 58, no. 1.

Manne, H. (1966). Insider Trading and the Stock Market. New York: Free Press.

Zeng, Q. S. (2008) "Does the insider have the ability to choose the opportunity to sell itevidence from the Chinese listed companies to sell the stock?". Financial Research, no. 10, pp. 11-15.

Ba, S. S., Zhu, Y. Q. \& Zheng, H. (2008) "Why is the valuation center under the whole circulation market show a downward trend?”, Financial Development Research, no. 4, pp. 3-8.

Chen, X. D., \& Chen, X. Y. (2003) "Analysis of the influence of the largest shareholder on corporate governance and corporate performance", Economic Research Journal, no. 2, pp. 6474.

Wu, Y. H. \& Wu, S. N. (2010) "Study on emptying behavior of large shareholders in stock reduction process". China Industrial Economy, no. 5, pp. 121-130. 